\title{
Analisis Video Likes to Video Views Ratio Tiktok Pada \\ 5 Brand Lokal Di Indonesia
}

\author{
Putu Ade Permana \\ Putupermana7@gmail.com
}

\begin{abstract}
TikTok is a social media application launched by a Chinese company. TikTok allows users to create videos that are 15 to 16 seconds and 3 minutes long accompanied by music, filters, and several other creative features. In Indonesia, there are 30.7 million active users, making Indonesia the country with the largest TikTok users in the world. The large number of active TikTok users in Indonesia can certainly provide an opportunity for brands to make the TikTok platform a social media platform. marketing. There are 5 local brands in Indonesia that use TikTok as a marketing platform, namely: Aero Street, Ventela Shoes, Compass, Sage Footwear, and Piero Indonesia. The purpose of this study is to calculate the credibility of the TikTok account performance of the Top 5 Local Brands in Indonesia. The method used for this research is quantitative exploratory method. The results of this study indicate that the Compass Indonesia Local Brand is ranked first and has good account performance credibility.
\end{abstract}

\begin{abstract}
ABSTRAK
TikTok merupakan aplikasi sosial media yang diluncurkan oleh perusahaan asal Tiongkok. TikTok memungkinkan penggunanya membuat video berdurasi 15 sampai 16 detik dan 3 menit yang disertai dengan musik, filter, dan beberapa fitur kreatif lainnya. Di Indonesia ini terdapat 30,7 juta pengguna yang aktif sehingga menjadikan Indonesia sebagai negara dengan pengguna TikTok terbesar di dunia. Maraknya jumlah pengguna TikTok yang aktif di Indonesia tentu dapat memberikan peluang bagi brand untuk menjadikan platform TikTok sebagai platform sosial media marketing. Adapun 5 Brand Lokal di Indonesia yang memanfaatkan TikTok sebagai platform marketing, yaitu : Aero Street, Ventela Shoes, Compass, Sage Footwear, dan Piero Indonesia. Dengan tujuan dari penelitian ini yaitu untuk menghitung kredibilitas dari performa akun TikTok Top 5 Brand Lokal di Indonesia. Metode yang digunakan untuk penelitian ini yaitu metode eksploratif kuantitatif. Hasil dari penelitian ini menunjukan bahwa Brand Lokal Compass Indonesia mendapatkan peringkat pertama dan memiliki kredibilitas performa akun yang baik.
\end{abstract}

Keyword: Credibility Account TikTok ; Social Media Marketing ; Social Media TikTok ; Video Likes to Video Views Ratio ; Brand Lokal Indonesia. 


\section{PENDAHULUAN}

Teknologi Infomasi adalah salah satu unsur pokok dalam pembangunan yang terencana. Tanpa adanya perkembangan teknologi, maka perubahan zaman tidak akan secepat dan secanggih seperti sekarang. Adapun kecanggihan teknologi informasi yang kita nikmati saat ini merupakan buah hasil yang dimulai dari proses panjang puluhan atau bahkan ratusan tahun kebelakang. Media sosial memberikan pengaruh yang cukup besar, saat ini media sosial diajadikan sarana berkomunikasi dalam setiap aktifitas keseharian bersosial di masyarakat. Komunikasi tidak hanya dapat dilakukan secara fisik, tetapi juga dapat dilakukan dengan menggunakan berbagai aplikasi media sosial di dunia maya. Keunggulan layanan aplikasi sosial media adalah memberikan ruang komunikasi dua arah antara konsumen-perusahaan dan konsumen-konsumen.

Dengan perkembangan teknologi media sosial, telah memberikan dampak terhadap situs-situs komunikasi, dari yang awalnya hanya sekedar email dan chatting, saat ini sudah banyak jejaring media sosial yang bisa digunakan sebagai alat komunikasi. Contoh aplikasi sosial media yang memiliki banyak pengguna saat ini yaitu TikTok. TikTok merupakan aplikasi yang diluncurkan oleh perusahaan asal Tiongkok. Tiktok memungkinkan penggunanya membuat video berdurasi 15 sampai 16 detik dan 3 menit yang disertai dengan musik, filter, dan beberapa fitur kreatif lainnya.

Aplikasi TikTok adalah sebuah aplikasi di mana para penggunanya bisa berbagi video musik dengan durasi pendek. Selain nama TikTok, dia juga dikenal dengan Douyin, sebuah video pendek vibrato. TikTok dikenalkan dan diluncurkan pertama kali pada September 2016. Pada saat itu, aplikasi ini langsung diterima di Indonesia. Namun memang, saat itu banyak yang menyebut pengguna TikTok sebagai seorang alayers. Kabar miring soal aplikasi ini tak berhenti di situ. Indonesia pada Juli 2018, melalui Menkominfo, Pak Rudiantara, sempat memblokir TikTok. Aplikasinya dinilai tidak ramah anak. Hal ini dibuktikan dari laporan dan komplain dari ribuan pengguna. Di dalamnya ada banyak sekali konten negatif yang seharusnya tidak dipertontonkan kepada anak-anak. Baru sepekan kemudian, TikTok bisa akses oleh pengguna Indonesia lagi. Hal ini terjadi setelah Tim TikTok melakukan negosiasi dan mengganti Term and Condition soal usia, dll. agar aksesnya bisa terbatas dan tak terlalu bebas. Maraknya jumlah pengguna TikTok aktif di Indonesia tentu dapat memberikan peluang bagi brand untuk menjadikan platform ini sebagai platform sosial media marketing. Cukup banyak akun perushaan-perusahaan terkenal yang ada pada tiktok, contohnya seperti vendor smartphone di Indonesia. Adapun Top 5 Brand Lokal di Indonesia, diantaranya yaitu : Aero Street, Ventela Shoes, Compass, Sage Footwear, dan Piero.

Penelitian ini menggunakan metode eksploratif kuantitatif, dan akan menghitung menggunakan rasio-rasio yang ada pada TikTok. Pada Penelitian ini terdapat 17 rasio yang ada pada sosial media TikTok dan relevanndigunakan sebagai media ukur kredibilitas akun yang ada. Penelitian ini hanya berfokus untuk menghitung kredibilitas Video Likes to Video Views Ratio pada Top 5 Vendor Smartphone di Indonesia. Adapun Top 5 Brand Lokal Aero Street, Ventela Shoes, Compass, Sage Footwear, dan Piero. Tujuan dari penelitian 
ini adalah mengetahui kredibilitas performa dari akun TikTok Top 5 Brand Lokal di Indonesia menggunakan Video Likes to Video Views Ratio.

\section{TINJAUAN PUSTAKA}

Perkembangan teknologi saat ini sangat pesat melalui perkembangan dari waktu ke waktu yang menimbulkan maraknya banyak aplikasi serta platform media sosial yang bermunculan. Aplikasi yang sangat diminati oleh masyarakat saat ini diantaranya adalah TikTok, Instagram, Twitter, WhatsApp dan yang lain sebagainya. Seiring berjalannya waktu, aplikasi sosial media tersebut dapat menjadi candu bagi kalangan masyarakat. Tidak hanya kalangan remaja yang menggunakan aplikasi sosial media, orang tua bahkan anakanak juga aktif menggunakan aplikasi sosial media tersebut.

Tiktok merupakan bagian dari new media yang memiliki perkembangan terpesat dibandingkan dengan kategori new media yang lainnya seperti facebook, Instagram, YouTube, dan Twitter dari sekian banyak aplikasi sosial media, TikTok menjadi aplikasi yang memiliki pengguna aktif terbanyak. TikTok merupakan jejaring sosial media dalam bentuk video yang umumnya berdurasi 15 detik. Pada aplikasi TikTok pengguna dapat membuat video dengan filter-filter yang spesial serta menggunakan lagu yang sedang trending. Selain itu, pengguna dapat membagikan video yang dibuat ke aplikasi lain seperti Instagram atauoun Twitter salah satunya ciri khas sosial media TikTok adalah halaman utamanya yang Bernama For Your Page atau FYP. Pengguna yang cukup sering ditayangkan dalam FYP dapat menjadi popular dan memiliki banyak pengikut, yang biasa disebut sebagai seleb TikTok (Putri and Azeharie 2021).

Di Indonesia, fenomena anak muda dalam menggunakan TikTok menunjukan antusiasme yang sangat massif. Aplikasi TikTok semakin populer sejak diluncurkan tahun 2016. Bahkan TikTok telah mencetak berbagai macam prestasi, salah satunya yaitu menyalip pendapatan iklan digital di negatanya yaitu pendapat Google. Aplikasi TikTok tidak hanya digunakan untuk membuat konten video dengan tujuan menghibur pengguna lainnya. Aplikasi TikTok juga dapat dijadikan peluang bagi brand atau perusahaan sebagai platform social media marketing. Penelitian (Purnamasari and Tutiasri 2021) menyatakan bahwa TikTok berpengaruh positif dan signifikan terhadap minat beli atau berbelanja secara online. Sehingga dengan ini, TikTok mampu memberikan peluang yang sangat tinggi bagi perusahaan-perusahaan dalam melakukan digital marketing.

Aplikasi TikTok ini banyak dirasakan memiliki kekuatan ataupun pengaruh dalam industri, sehingga menimbulkan kualitas akun yang menentukan strata maupun kredibilitas pemilik akun. Kredibilitas akun TikTok merupakan suatu hal yang cukup penting untuk berbagai kepentingan. Kredibilitas sebuah akun TikTok dapat diukur dari tingkat performa yang dihasilkan secara matematis. Dalam mengukur performa diperlukan skala pengukuran yang tertuang ke dalam rasio. 


\section{METODE PENELITIAN}

Penelitian ini menggunakan metode eksploratif kuantitatif untuk mengetahui kredibilitas dari performa akun TikTok 5 Brand Lokal di Indonesia. Metode eksploratif merupakan penelitian yang memiliki tujuan untuk melakukan eksplorasi atau memperdalam pengetahuan ataupun ide-ide baru mengenai suatu hal yang baru, guna merumuskan permasalahan secara terperinci (Maryam, Isrok'atun, and Aeni 2016) .

Tujuan dari penelitian ini yaitu mengetahui nilai kredibillitas dari performa akun TikTok 5 Brand Lokal di Indonesia. Ada beberapa langkah yang harus dilakukan dalam penelitian ini, sehingga mampu menemukan peringkat pertama akun TikTok Brand Lokal di Indonesia yang memiliki performa terbaik. Langkah-langkah yang dilakukan pada penelitian ini, diantaranya yaitu :

\section{Melakukan Eksplorasi Pada Website Untuk Menentukan Objek yang Akan Dianalisa.}

Eksplorasi ini dilakukan pada beberapa halaman website yang menyediakan informasi mengenai objek yang akan di teliti. Setelah ekslorasi selesai dilakukan, sehingga ditemukan nama-nama Brand Lokal di Indonesia yang akan dijadikan objek analisa. Setelah melakukan eksplorasi pada halaman website, maka langkah selanjutnya yaitu mencari nama akun TikTok dari masing-masing Brand Lokal. Pastikan semua Brand Lokal memiliki akun pada aplikasi sosial media TikTok.

\section{Menghitung Nilai Rata-Rata Variable Dari Top 5 Brand Lokal di Indonesia.}

Pada langkah ini, peneliti menghitung nilai variable video comments dan variable video likes. Variabel merupakan sesuatu yang memiliki nilai bervariasi dimana nilai tersebut dapat dijadikan sebagai dasar untuk empat data yang berbeda seperti rasio, skala, ordinal, nominal dan internal (Rankuti 2015) . Untuk menghitung nilai rata-rata dari variabel video likes dan variabel video views yaitu dengan cara mengambil minimal 10 postingan kemudian di hitung sehingga menemukan nilai rata-rata dari masing-masing variabel.

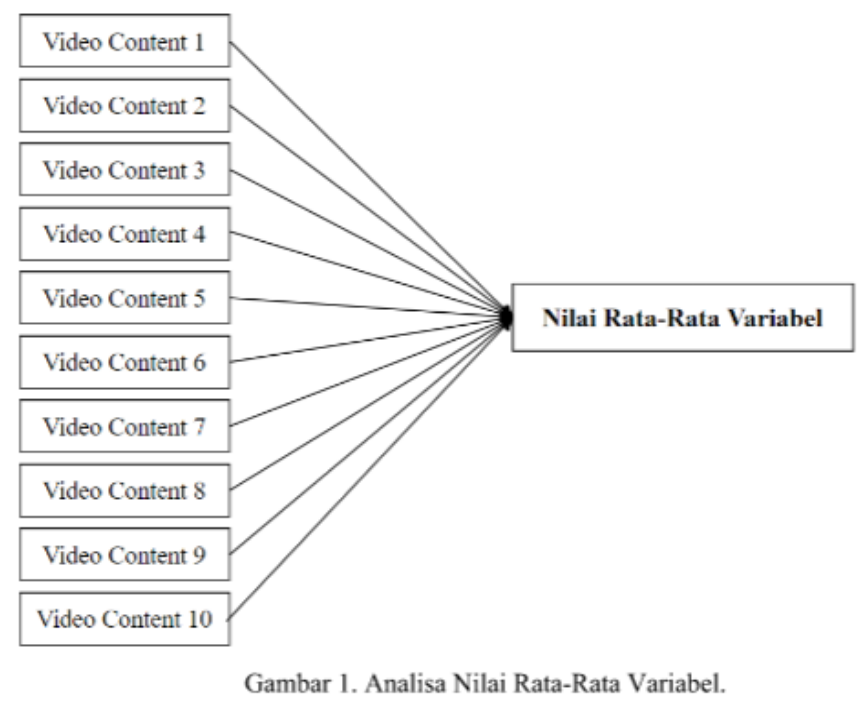




\section{Menghitung Nilai Kredibilitas Rasio}

Untuk menghitung nilai kredibilitas dari video likes to video views ratio, peneliti menggunakan cara membagi nilai variabel pertama dengan nilai variabel kedua. Jika video likes memiliki nilai 100 dan video views memiliki nilai 300, maka cara menghitungnya yaitu $100: 300=0,3$. Dengan begitu nilai dari video comments to video views ratio adalah 0,3 .

\section{Menentukan Peringkat Pada Akun TikTok}

Pada langkah terakhir yang dilakukan pada penelitian ini yaitu menentukan peringkat pada masing-masing rasio yang ada. Pada penentuan peringkat perlu melihat karakteristik dari rasio yang di teliti. Jika karakteristik rasio merupakan rendah, maka objek yang memiliki nilai terendah akan mendapatkan angka 5 dan objek yang memiliki nilai tertinggi akan mendapatkan angka 1. Namun jika rasio memiliki karakteritik tinggi maka objek yang mendapatkan nilai tinggi akan mendapatkan angka 5 dan objek yang mendapatkan nilai terendah akan mendapatkan angka 1. Setelah mendapatkan hasil kredibilitas ratio maka dapat disimpulkan objek yang mana mendapatkan peringkat 1 sampai dengan peringkat 5 .

\section{HASIL DAN PEMBAHASAN}

Akun TikTok dari 5 Brand Lokal Di Indonesia, diantaranya:

\section{Aero Street}

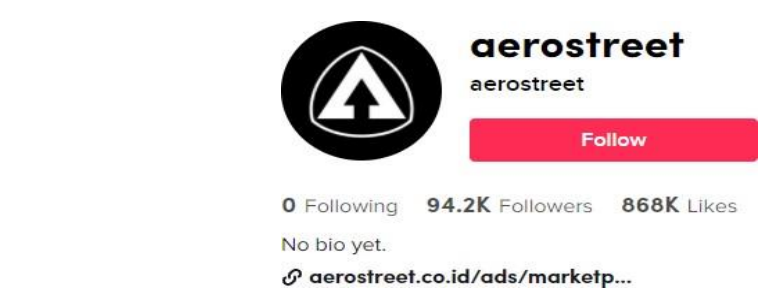

Gambar 1. Akun TikTok Aero Street

Sumber : https://www.tiktok.com/@aerostreet (akses pada 21-10-2021)

\section{Ventela Shoes}

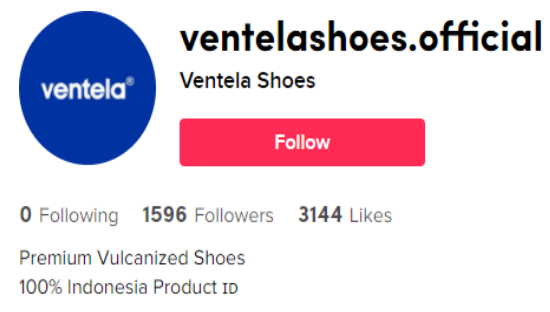

Gambar 2. Akun TikTok Ventela Shoes 


\section{Compass}

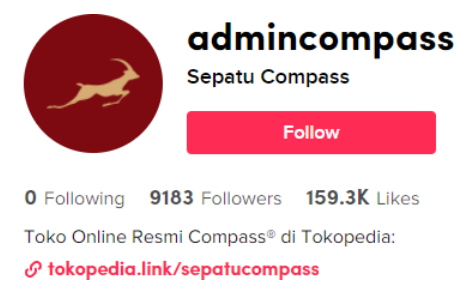

Gambar 3. Akun TikTok compass

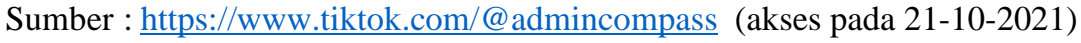

\section{Sage Footwear}

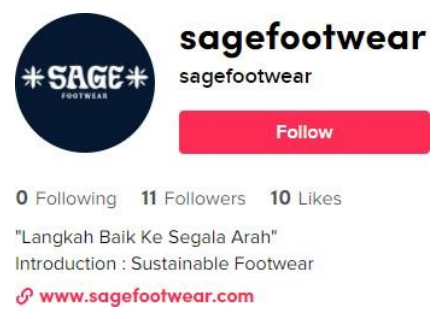

Gambar 4. Akun TikTok Sage Footwear

Sumber : $\underline{\text { https://www.tiktok.com/@sagefootwear (akses pada 21-10-2021) }}$

\section{Piero Indonesia}

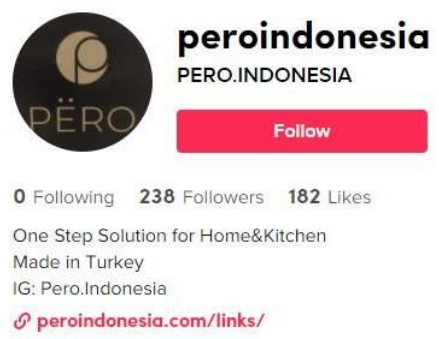

Gambar 5. Akun TikTok Piero Indonesia

Sumber : https://www.tiktok.com/@peroindonesia (akses pada 21-10-2021)

Dari kelima akun TikTok 5 Brand Lokal Di Indonesia, peneliti menemukan nilai dari masingmasing variabel yang ada untuk menghitung rasio Video Likes to Video Views dari setiap akun. Pada akun TikTok terdapat 7 variabel, diantaranya yaitu:

1. Likes

2. Followers

3. Following

4. Video Likes

5. Video Comments

6. Video Share 


\section{Video Views}

Dari ketujuh variabel tersebut peneliti hanya fokus untuk menemukan hasil dari 2 variabel, yaitu :

1. Video Likes

2. Video Views

Dari kedua variabel tersebut kemudian dianalisa sehingga menemukan nilai rata-rata dari variabel video likes dan variabel video views. Untuk menghitung nilai rata-rata dari variabel video likes dan variabel video views yaitu dengan cara mengambil minimal 10 postingan kemudian di hitung sehingga menemukan nilai rata-rata dari masing-masing variabel. Berikut merupakan tabel nilai rata-rata dari masing-masing brand lokal di Indonesia, yaitu:

Tabel 1. Analisa Nilai Rata-Rata Nilai Variabel Video Likes dan Video Views Akun TikTok Aero Street

\begin{tabular}{|c|c|c|}
\hline No & Video Likes & Video Views \\
\hline 1 & 675 & 13500 \\
\hline 2 & 297600 & 20700 \\
\hline 3 & 477 & 15300 \\
\hline 4 & 169 & 10600 \\
\hline 5 & 9832 & 114600 \\
\hline 6 & 266 & 10000 \\
\hline 7 & 202 & 7898 \\
\hline 8 & 304 & 10600 \\
\hline 9 & 745 & 14100 \\
\hline 10 & 279 & 8196 \\
\hline Total & $\mathbf{3 1 0 5 4 . 9}$ & $\mathbf{2 2 5 4 9 . 4}$ \\
\hline
\end{tabular}


Tabel 2. Analisa Nilai Rata-Rata Nilai Variabel Video Likes dan Video Views AkunTikTok Ventela Shoes

\begin{tabular}{|c|c|c|}
\hline No & $\begin{array}{c}\text { Video } \\
\text { Likes }\end{array}$ & $\begin{array}{c}\text { Video } \\
\text { Views }\end{array}$ \\
\hline 1 & 142 & 12000 \\
\hline 2 & 258 & 18900 \\
\hline 3 & 1923 & 58100 \\
\hline 4 & 772 & 29900 \\
\hline & & \\
\hline Total & 773.75 & 29725 \\
\hline
\end{tabular}

Sumber: Pengolah Data Exel

Tabel 3. Analisa Nilai Rata-Rata Nilai Variabel Video Likes dan Video Views AkunTikTok Compass

\begin{tabular}{|c|c|c|}
\hline No & Video Likes & Video Views \\
\hline 1 & 954900 & 74900 \\
\hline 2 & 2746 & 470 \\
\hline 3 & 36900 & 2750 \\
\hline 4 & 5393 & 537 \\
\hline 5 & 2216 & 149 \\
\hline 6 & 1482 & 45 \\
\hline 7 & 205300 & 13800 \\
\hline 8 & 2437 & 187 \\
\hline 9 & 1669 & 95 \\
\hline 10 & 3399 & 364 \\
\hline Total & $\mathbf{1 2 1 6 4 4 . 2}$ & $\mathbf{9 3 2 9 . 7}$ \\
\hline
\end{tabular}

Sumber: Pengolah Data Excel 
Tabel 4. Analisa Nilai Rata-Rata Nilai Variabel Video Likes dan Video Views AkunTikTok Sage Footwear

\begin{tabular}{|c|c|c|}
\hline No & $\begin{array}{c}\text { Video } \\
\text { Likes }\end{array}$ & $\begin{array}{c}\text { Video } \\
\text { Views }\end{array}$ \\
\hline 1 & 4 & 153 \\
\hline 2 & 6 & 118 \\
\hline Total & 5 & 135.5 \\
\hline
\end{tabular}

Sumber: Pengolah Data Excel

Tabel 5. Analisa Nilai Rata-Rata Nilai Variabel Video Likes dan Video Views AkunTikTok Piero Indonesia

\begin{tabular}{|c|c|c|}
\hline No & $\begin{array}{c}\text { Video } \\
\text { Likes }\end{array}$ & $\begin{array}{c}\text { Video } \\
\text { Views }\end{array}$ \\
\hline 1 & 2 & 17 \\
\hline 2 & 2 & 3 \\
\hline 3 & 2 & 28 \\
\hline Total & $\mathbf{2}$ & $\mathbf{1 6}$ \\
\hline
\end{tabular}

Sumber: Pengolah Data Excel

Setelah menghitung nilai rata-rata tersebut, maka akan menemukan hasil akhir nilai rata-rata dari variabel video likes dan video views

Tabel 6. Nilai Variabel Pada Akun TikTok 5 brand lokal di Indonesia

\begin{tabular}{|c|c|c|c|c|c|}
\hline Variabel & Aero Street & Ventela Shoes & Compass & $\begin{array}{c}\text { Sage } \\
\text { Footwear }\end{array}$ & $\begin{array}{c}\text { Piero } \\
\text { Indonesia }\end{array}$ \\
\hline Video Likes & 31054.9 & 773.5 & 121664.2 & 5 & 2 \\
\hline Video Views & 22549.4 & 29725 & 9329.7 & 135.5 & 16 \\
\hline
\end{tabular}

Sumber: Pengolah Data Excel 
Pada akun TikTok terdapat 7 rasio yang relevan digunakan untuk mengukur kredibilitas pada masing-masing akun. Namun pada penelitian kali ini hanya berfokus untuk menghitung Video Likes to Video Views Ratio. Untuk menghitung kredibilitas dari masing-masing akun TikTok setiap vendor brand lokal, peneliti menghitung dengan cara : variabel 1 akan dibagi dengan variabel 2, sehingga ditemukan hasil analisisa dari rasio tersebut.

Tabel 7. Hasil Perhitungan Rasio Akun TikTok

\begin{tabular}{|l|l|l|l|l|c|}
\hline \multicolumn{1}{|c|}{ Ratio } & Aero Street & Ventela Shoes & Compass & $\begin{array}{l}\text { Sage } \\
\text { Footwear }\end{array}$ & $\begin{array}{l}\text { Piero } \\
\text { Indonesia }\end{array}$ \\
\hline $\begin{array}{l}\text { Video Likes } \\
\text { \& Video } \\
\text { Views }\end{array}$ & 1.377194072 & 0.026021867 & 13.04052649 & 0.036900369 & 0.125 \\
\hline
\end{tabular}

Sumber: Pengolah Data Excel

Video Likes to Video Views Ratio memiliki karakteristik yang tinggi, artinya semakin tinggi nilai yang dihasilkan maka semakin baik kredibilitas dari performa akun tersebut. Untuk memberikan peringkat pada masing-masing Vendor Brand Lokal, peneliti memberikan angka 5 kepada vendor yang mendapatkan nilai tertinggi dan angka 1 untuk vendor brand lokal yang mendapatkan nilai terendah. Berikut merupakan tabel urutan nilai yang dihasilkan oleh masingmasing vendor brand lokal.

Tabel 8. Nilai Rasio Akun TikTok 5 brand lokal di Indonesia

\begin{tabular}{|c|c|c|c|c|c|}
\hline Ratio & Aero Street & $\begin{array}{c}\text { Ventela } \\
\text { Shoes }\end{array}$ & Compass & $\begin{array}{c}\text { Sage } \\
\text { Footwear }\end{array}$ & $\begin{array}{c}\text { Piero } \\
\text { Indonesia }\end{array}$ \\
\hline $\begin{array}{l}\text { Video Likes } \\
\text { \& Video } \\
\text { Views }\end{array}$ & 2 & 5 & 1 & 4 & 3 \\
\hline
\end{tabular}

Sumber: Pengolah Data Excel

Dari Tabel Nilai Rasio Akun TikTok 5 Brand Lokal di Indonesia dapat simpulkan bahwa compass mendapatkan nilai tertinggi untuk rasio Video likes to Video Views. Sedangkan akun TikTok Ventela Street mendapatkan nilai terendah untuk rasio ini. Jadi, pada penelitian ini memiliki kredibilitas performa yang lebih baik dibandingkan dengan brand lokal yang lainnya. 


\section{KESIMPULAN}

Tujuan dari penelitian ini adalah mengetahui kredibilitas performa dari akun TikTok Top 5 Brand Lokal di Indonesia menggunakan Video likes to Video Views Ratio. Top 5 Brand Lokal tersebut diantaranya: Aero Street, Ventela Shoes, Compass, Sage Footwear, dan Piero. Dari kelima Brand Lokal tersebut dapat disimpulkan bahwa:

1. Peringkat pertama diraih oleh Brand Lokal Compass Indonesia dengan nilai tertinggi yaitu 13.04052649

2. Peringkat kedua diraih oleh Brand Lokal Aero Street Indonesia dengan nilai 1.377194072

3. Peringkat ketiga diraih oleh Brand Lokal Piero Indonesia dengan nilai 0.125

4. Peringkat keempat diraih oleh Brand Lokal Sage Footwear Indonesia dengan nilai 0.036900369

5. Peringkat kelima diraih oleh Brand Lokal Ventela Shoes Indonesia dengan nilai terendah yaitu 0.026021867 


\section{DAFTAR PUSTAKA}

Referensi 1.(Tik Tok Adalah (Pengertian), Asal, Manfaat, Efek Negatifnya | Social Media Marketing Specialist, n.d.)

Referensi 2(5 Brand Sepatu Lokal Terbaik Di Tahun 2021, Kualitas Terbaik Dengan Harga Terjangkau! - Semua Halaman - Stylo, n.d.)

Referensi 3(Wijaya \& Mashud, 2020)

5 Brand Sepatu Lokal Terbaik di Tahun 2021, Kualitas Terbaik dengan Harga Terjangkau! Semua Halaman - Stylo. (n.d.). Retrieved November 17, 2021, from https://stylo.grid.id/read/142883794/5-brand-sepatu-lokal-terbaik-di-tahun-2021-kualitasterbaik-dengan-harga-terjangkau?page=all

Pengaruh Media Sosial Terhadap Perilaku Masyarakat<p style="text-align:justify" >Penggunaan sarana media komunikasi saat ini telah berkembang begitu pesat seiring dengan kemajuan teknologi komunikasi, dimana kita diperhadapkan kepada banyak pilihan un... (n.d.).

Retrieved November 17, 2021, from https://sulselprov.go.id/welcome/post/pengaruh-mediasosial-terhadap-perilaku-masyarakat

Tik Tok Adalah (Pengertian), Asal, Manfaat, Efek Negatifnya| Social Media Marketing Specialist. (n.d.). Retrieved November 17, 2021, from https://pojoksosmed.com/tiktok/tik-tok-adalah/ Wijaya, M. H. dwi, \& Mashud, M. (2020). Konsumsi Media Sosial Bagi Kalangan Pelajar: Studi Pada Hyperrealitas Tik Tok. Al-Mada: Jurnal Agama, Sosial, Dan Budaya, 3(2), 170-191. https://doi.org/10.31538/ALMADA.V3I2.734

Adawiyah, Dwi Putri Robiatul. 2020. "Pengaruh Penggunaan Aplikasi TikTok Terhadap Kepercayaan Diri Remaja Di Kabupaten Sampang.” Jurnal Komunikasi 14 (2): 135-48. https://doi.org/10.21107/ilkom.v14i2.7504. 
